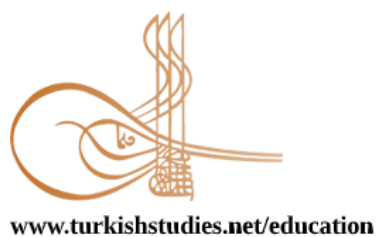

Turkish Studies - Educational Sciences

\title{
Bilim ve Sanat Merkezi Öğretmenlerinin Yaşadıkları Sorunlar ve Bu Sorunlara İlişkin Çözüm Önerilerinin Belirlenmesi*
}

\author{
Science and Art Center Teachers' Problems and Solution Proposals For These Problems
}

\author{
İbrahim Bozan ${ }^{* *}$ - Firdevs Savi Çakar***
}

\begin{abstract}
The aim of this research is to reveal the problems faced by teachers working in Science and Art Centers and their solutions. Research is a qualitative study with an integrated multi-state pattern. The study group consisted of 30 teachers working at two Science and Art Center in Antalya. As a data collection tool, semi-structured interview forms consisting of open-ended questions were used. Taking into account the characteristics of the data collection tool, the data were analyzed by content analysis. Based on this data analysis, findings and interpretations of the research were formed. The findings of the research were given in tables, frequency and percentage values were given and direct excerpts were taken from the students' opinions. According to the results of the study, it is determined that teachers have many problems in personal, educational and managerial areas. As a personal problem, teachers intensely state that the teaching hours in Science and Art Centers are not suitable for both teachers and students. The most frequently mentioned problems in the educational sense of the teachers are the lack of equipment and materials in the center where they work, the inadequate physical facilities of the centers, and the content of the activities in the framework programs of the Science and Art Centers. The lack of communication with the administrators, the result-oriented thinking of the managers due to the success of the institution and the lack of fairness in terms of the opportunities offered to the teachers emerge as the administrative problems expressed by the teachers. As a solution to the problems experienced, teachers often suggest that working hours at BILLSEMs should be brought up to date and MEB should provide support to BİLSEM on physical equipment. The findings of the research are discussed in the light of the literature and recommendations are presented.
\end{abstract}

Structured Abstract: Introduction: In recent years, Science and Art Centers and gifted students have identified with each other and Science and Art Centers have started to gain an important place in the education

\footnotetext{
* Çalışmada kullanılan veriler 2019 yılında elde edilmiştir.

*** Öğretmen, Antalya Bilim ve Sanat Merkezi; Doktora öğrencisi, Mehmet Akif Ersoy Üniversitesi, Eğitim Bilimleri Enstitüsü, Sınıf Eğitimi

Teacher, Antalya Science and Art Center; Phd Student, Mehmet Akif Ersoy University, Institute of Educational Sciences, Primary Education

ORCID 0000-0002-7666-6664

ibrahimbozan7@gmail.com

*** Doç. Dr., Mehmet Akif Ersoy Üniversitesi, Eğitim Fakültesi, Rehberlik ve Psikolojik Danışmanlık ABD.

Assoc. Prof. Dr. Mehmet Akif Ersoy University, Faculty of Education, Guidance \& Counseling Department

ORCID 0000-0001-5322-0443

firdevssavi@mehmetakif.edu.tr

Cite as/ Atıf: Bozan, İ. \& Savi Çakar, F. (2020). Bilim ve sanat merkezi öğretmenlerinin yaşadıkları sorunlar ve bu sorunlara ilişkin çözüm önerilerinin belirlenmesi. Turkish Studies - Education, 15(3), 1607-1628. https://dx.doi.org/10.29228/TurkishStudies.39986

Received/Geliş: 02 December/Aralık 2019

Accepted/Kabul: 21 June/Haziran 2020

Copyright (C) INTAC LTD, Turkey

Checked by plagiarism software

Published/Yayın: 25 June/Haziran 2020

CC BY-NC 4.0
} 
of gifted students. However, many problems arise in these centers, especially problems related to the efficient education of the students.

Science and Art Centers have a very important place for the future of our country because of meeting the educational needs of gifted students different from their peers. Educators working in these institutions; students may face different problems such as orientation, lack of materials and equipment, and parents' pressure (Karaduman and Ceviz, 2018). The opinions of teachers working in BILSEMs are important for identifying these problems and presenting solutions. A very important mission for the education of gifted teachers in Science and Art Centers in Turkey, where they live and fewer problems related to studies presented solutions to these problems. Therefore, this study will contribute to the literature in order to identify the problems faced by teachers and their solutions.

The aim of this study is to reveal the problems faced by the teachers of Science and Art Center in their institutions and their suggestions for solutions to these problems. For this purpose, answers to the following questions will be sought.

1. What are the personal problems experienced by teachers working in Science and Art Centers?

2. What are the educational problems experienced by teachers in the Science and Art Center?

3. What are the administrative problems of teachers working in Science and Art Centers?

4. What are the teachers' solution suggestions for the problems?

\section{Research Model}

In the study, one of the qualitative research designs, holistic multi case study design was used. "Case studies, case study models are screening arrangements aiming to reach a judgment about a particular unit in the universe (individual, family, school, hospital association, etc.) by determining the depth and breadth of the unit and its relationship with itself and its environment" (Karasar), 2005, p.86). "As the name implies, there are more than one analysis unit such as individuals, institutions, programs and schools. One of the uses of this pattern is that no one has ever worked or reached ulaş (Yıldırım ve Şimşek, 2013).

In the research, semi-structured interview form was used as a qualitative data collection tool: According to Karasar (2005), individual interviews were of the type that no one other than the interviewee had interviewed. In this type of interview, more personal information is obtained. The content validity of the interview questions was obtained by taking expert opinions. The experts were interviewed by a faculty member and two teachers working in the Science and Art Center.

The data of the research was analyzed by content analysis. According to Fox (1969), content analysis is the classification of verbal and written data in terms of a specific problem or purpose, the measurement of certain variables or concepts, and the screening of these data into categorization (Yalçın et al., 2009, p.3). The main purpose of content analysis is to reach the concepts and relationships that can explain the collected data. Qualitative research data is analyzed in four stages: coding of data, finding themes, arranging codes and themes, defining and interpreting findings (Yıldırım ve Şimşek, 2013).

\section{Findings, Discussion and Results}

As a result of the research, the problems of the teachers emerged in three dimensions as personal, educational and managerial problems. In addition, teachers gave suggestions about what can be done to solve these problems.

If the personal problems experienced by teachers are interpreted; The personal problem that teachers experience most is that their working hours are not suitable. The fact that the courses are on weekdays, evenings and Saturdays in BİLSEMs affects teachers' lives in many ways. The findings obtained in the study coincide with the results of Çetin and Doğan (2018).

When interpreting the educational problems experienced by teachers; It is seen that almost all of the teachers experience lack of educational equipment and materials. At the same time, technological support and internet infrastructure are insufficient in the classrooms. According to the research conducted by Sar1 and Ögülmüş (2014), it was determined that the activities could not be fully realized in Science and Art Centers due to lack of resources and materials. Another problem that teachers have stated intensively is that the 
activities included in the framework programs of Science and Art Centers contain problems in terms of content. Some activities cause gifted students to get bored. In their study, Çetin and Doğan (2018) found that the sequence, duration and level of activities included in the framework curriculum were not appropriate, contained scientific errors, did not attract students' interest, and did not correspond to the curriculum implemented in schools. These results are similar to the findings of this study.

When the problems experienced by teachers in managerial perspective are examined, it is seen that they have communication problems with administrators. The most important reason for this problem is that managers think results-oriented for the success of the organization. Managers expect teachers to make projects and achieve success across the country. In addition, administrators do not act equally on the opportunities offered to teachers. Some of the teachers have classes of 3-4 students, while some of them have classes of 1520 students. This makes the student groups unstable.

When the suggestions of the teachers about the problems were examined, the teachers made a suggestion that the working hours in Science and Art Centers should be the same as in normal schools during the working hours. For this purpose, the Ministry of National Education can make arrangements for students to free their day in their schools and come to BILSEM more easily. This will increase the motivation of both teachers and students. Teachers stated that as a solution to the problems of lack of equipment and materials, the appropriations given to BİLSEM should be increased. In this way, the BİLSEMs can be supported in terms of physical equipment.

Keywords: Education Sciences, Science and Art Centers, teacher of gifted students, problems of teachers, gifted students.

Öz: Araştırmada Bilim ve Sanat Merkezlerinde görev yapan öğretmenlerin karşılaştıkları sorunlar ve bu sorunlara ilişkin çözüm önerilerinin ortaya koyulması amaçlanmaktadır. Araştırma bütüncül çoklu durum çalışması deseninde nitel bir çalışmadır. Araştırmanın çalışma grubunu, Antalya ilinde iki Bilim ve Sanat merkezinde görev yapan 30 öğretmen oluşturmaktadır. Veri toplama aracı olarak, araştırmacılar tarafından hazırlanan açık uçlu sorulardan oluşan yarı yapılandırılmış görüşme formu kullanılmıştır. Veri toplama aracı ile elde edilen veriler içerik analizi ile incelenmiştir. Araştırmanın bulguları frekans ve yüzde değerleri verilerek ve katılımcıların görüşlerinden doğrudan alıntılar yapılarak tablolar halinde sunulmaktadır. Çalışmanın sonuçlarına göre, öğretmenlerin kişisel, eğitsel ve yönetsel alanlarda birçok sorunlar yaşadıkları tespit edilmektedir. Öğretmenler kişisel sorun olarak Bilim ve Sanat Merkezlerinde ders saatlerinin hem öğretmenler hem de öğrenciler için uygun olmadığını yoğun olarak ifade etmektedirler. Öğretmenlerin eğitsel anlamda en çok dile getirdikleri sorunlar, çalıştıkları merkezde araç-gereç ve materyal eksikliği yaşamaları, merkezlerin fiziki donanım olarak yetersiz olması, Bilim ve Sanat Merkezlerinin çerçeve programlarında yer alan etkinliklerin içerik bakımından sorunlar içermesidir. Yöneticilerle iletişim sıkıntısı yaşama, yöneticilerin kurumun başarısı nedeniyle sonuç odaklı düşünmeleri ve öğretmenlere sunulan olanaklar açısından adaletli olmamaları ise öğretmenler tarafından dile getirilen yönetsel sorunlar olarak ortaya çıkmaktadır. Öğretmenler yaşanan sorunlara çözüm olarak çoğunlukla, BİLSEM'lerde çalışma saatlerinin gündüze alınması ve MEB'in BİLSEM'lere fiziki donanım konusunda destek sağlaması önerilerini sunmaktadır. Araştırmada elde edilen bulgular literatür ışığında tartışılarak öneriler sunulmaktadır.

Anahtar Kelimeler: Eğitim Bilimleri, Bilim ve Sanat Merkezleri, üstün yetenekliler öğretmeni, öğretmenlerin sorunları, üstün yetenekli öğrenci.

\section{Giriş}

Bilim ve Sanat Merkezleri (BİLSEM); örgün eğitim kurumlarına devam eden; genel zihinsel, görsel sanatlar veya müzik yetenek alanlarında özel yetenekli olan öğrencilere, yeteneklerini geliştirerek kapasitelerini en üst düzeyde kullanmalarını sağlamak amacıyla açılmış olan bağımsız özel eğitim kurumlarıdır (Özel Eğitim Hizmetleri Yönetmeliği, 2018). Türkiye'de ilk olarak 1994-1995 eğitim öğretim yılında Ankara'da açılan Bilim ve Sanat Merkezleri, günümüzde 81 ilde 160 merkezde hizmet vermektedir. 
Türkiye'de özellikle son birkaç yılda BİLSEM'lerin sayısı hızla artarken bu kurumların nitelikli öğretmen ihtiyacı da artmaktadır. BİLSEM'lere öğretmen atamaları Milli Eğitim Bakanlığı tarafından her yıl yayınlanan Bilim ve Sanat Merkezleri Öğretmen Seçme ve Atama Kılavuzuna göre yapılmaktadır. Kılavuza göre öğretmenler belirli koşulları yerine getirmek zorundadır. İlk aşamada başvuran öğretmenlerin Değerlendirme Kriterleri Formu üzerinden puanı belirlenir. Bu süreçte; öğretmenlerin yüksek lisans, doktora eğitimleri, YÖKDİL-YDS puanları, proje gerçekleştirme, makale yazma, bildiri sunma, kitap yazma, gibi ölçütler dikkate alınmaktadır. İkinci aşamada ise Bakanlıkça belirlenen bölge merkezlerinde kurulan komisyonlar tarafindan Sözlü Sinav yapılmaktadır (MEB, 2018). Bilim ve Sanat merkezlerinde görev yapan öğretmenlerin eğitim durumlarına bakıldığı çoğunluğunun yüksek lisans ve doktora mezunu olduğu ortaya çıkmaktadır.

Son yıllarda Bilim ve Sanat Merkezleri ve üstün yetenekli öğrenciler birbiriyle özdeşleşmiş, Bilim ve Sanat Merkezleri üstün yetenekli öğrencilerin eğitimlerinde önemli bir yer edinmeye başlamıştır. Ancak bu merkezlerde öğrencilerin verimli bir eğitim almasıyla ilgili problemler başta olmak üzere birçok sorun baş göstermektedir.

Üstün yetenekli öğrencilerin normal öğretim ortamlarında sunulan eğitim öğretim anlayışından daha farklı öğrenme ihtiyaçlarına gereksinimleri bulunmaktadır. Bu öğrencilerin özel yeteneklerini en üst seviyeye çıarabilmek için onlara farklı deneyimler yaşatabilecek ortamlar sağlanmalı ve öğrenme deneyimlerinin kalitesinin geliştirecek fırsatlar sunulmalıdır. Bu sebeple bilim sanat merkezlerinin yapısı, öğrencilere uyguladığı etkinlikler, fiziki donanımları yönünden diğer kurumlardan farklı yapıda olmalıdır. Üstün yetenekli öğrencilerin eğitiminde kullanılan öğretim yöntem-tekniklerin, fiziksel donanım şartlarının, öğretim materyallerin eksik olması bilim sanat merkezlerin başarısını olumsuz bir şekilde etkilemektedir (Gökdere ve Çepni, 2003). BİLSEM öğretmenleri özellikle merkezlerde görülen araç-gereç, materyal ve kaynak eksikliğinden dolay1 üstün yetenekli öğrencilere yönelik hazırlanacak zenginleştirici etkinlikleri amacına uygun olarak gerçekleştirememektedirler (Sarı, 2013).

Üstün yetenekli öğrenciler de çevresindeki diğer arkadaşları gibi normal gelişimsel süreçleri yaşamaktadır. Ancak, üstün yeteneklilerin sahip oldukları bilişsel, sosyal ve duygusal farklılıklar, onların ergenliğin kritik dönemlerinde normal gelişim gösteren akranlarından farklı davranışlar gösterebileceklerini ortaya çıkarmaktadır. Örneğin, üstün yetenekli ergenlerde duygusal hassasiyet ve empati gibi özelliklerin, akranlarına oranla daha erken ortaya çıktığı bilinmektedir (Silverman, 1994). Bunun yanında, soyut ve karmaşık düşünebilme yeteneklerinin üstün yeteneklilerde daha çok gelişmiş olması da (Ataman, 2004) kimlik arayışının daha erken ortaya çıkabileceğini göstermektedir. Öte yandan, erken gelişen psikososyal özelliklerin akran gruplarına kabul açısından dezavantaj oluşturduğu ve üstün yetenekli ergenlerin zaman zaman kimlik gelișimi arayıșlarını ertelemelerine neden olabileceği de bilinmektedir (Gross, 1998). Böyle durumlarda öğrencilere öğretmenler ve ebeveynler tarafindan uygun destek sağlanamazsa üstün yetenekli öğrencilerde farklı davranış problemleri görülebilmektedir. Bu noktada çocukların sağlıklı bir kişilik gelişimi göstermeleri için aile ve öğretmen iletişiminin önemi büyüktür.

Bilim ve Sanat Merkezleri üstün yetenekli öğrencilerin akranlarından farklı eğitim ihtiyaçlarını karşılamasından dolayı ülkemizin geleceği için oldukça önemli bir yere sahiptir. Bu kurumlarda görevli olan eğitimciler; öğrenci yönlendirmesi, materyal ve donanım eksikliği, veli baskısı gibi farklı sorunlarla karşılaşabilmektedir(Karaduman ve Ceviz, 2018). Bu sorunların belirlenmesi ve çözüm önerilerinin sunulması açısından BİLSEM'lerde görev yapan öğretmenlerin görüşleri önemlidir. Türkiye'de özel yeteneklilerin eğitimi konusunda çok önemli bir misyonu olan Bilim ve Sanat Merkezlerinde öğretmenlerin yaşadıkları sorunlar ve bu sorunlara yönelik çözüm önerileri sunulması ile ilgili yapılan çalışma sayısı azdır. Bundan dolayı bu çalışma öğretmenlerin karşılaştıkları sorunların ve bu sorunlara yönelik çözüm önerilerinin tespit edilmesi bakımından alanyazına katkı sunacaktır. 
$\mathrm{Bu}$ çalışmanın amacı, Bilim ve Sanat Merkezi öğretmenlerinin görev yaptıkları kurumlarda karşılaştıkları sorunları ve bu sorunlara ilişkin çözüm önerilerini ortaya koymaktır. Bu amaç doğrultusunda aşağıdaki sorulara cevap aranacaktır.

1. Bilim ve Sanat Merkezlerinde çalışan öğretmenlerin yaşadığı kişisel sorunlar nelerdir?

2. $\quad$ Öğretmenlerin Bilim ve Sanat Merkezinde yaşadığı eğitsel sorunlar nelerdir?

3. Bilim ve Sanat Merkezlerinde çalışan öğretmenlerin yönetsel(idari) sorunlar nelerdir?

4. Yaşanan sorunlara ilişkin öğretmenlerin çözüm önerileri nelerdir?

\section{Yöntem}

Araştırmada nitel araştırma desenlerinden bütüncül çoklu durum çalışması deseni kullanılmıştır. "Durum çalışmaları, örnek olay tarama modelleri evrendeki belli bir ünitenin (birey, aile, okul, hastane dernek vb.nin), derinliğine ve genişliğine, kendisini ve çevresi ile olan ilişkilerini belirleyerek, o ünite hakkında bir yargıya varmayı amaçlayan tarama düzenlemeleridir" (Karasar, 2005, s. 86). "Bütüncül çoklu durum deseninde isminden anlaşılacağ 1 üzere birden fazla birey, kurum, program, okul gibi birçok analiz birimi vardır. Bu desenin kullanım alanlarından biri de daha önce kimsenin çalışmadığı veya ulaşamadığı durumlardır” (Yıldırım ve Şimşek, 2013).

\section{Çalışma Grubu}

Araştırma bütüncül çoklu durum desenine uygun olarak Antalya'da eğitim veren iki Bilim ve Sanat Merkezinde geçmiştir. Araştırmanın çalışma grubu kolay ulaşılabilir örnekleme yöntemine ve gönüllülük esasına göre seçilmiştir. Bu örnekleme yöntemi araştırmaya hız ve pratiklik kazandırmıştır. Araştırmanın yapıldığı kurumlarda görev yapan toplam 35 öğretmen bulunmaktadır. Araştırmanın çalışma grubunu, iki kurumda görev yapan 30 öğretmen oluşturmuştur.

Katılımcıların soruları içtenlikle cevaplamaları için isimleri belirtilmeyip kodlanarak araştırmacı tarafından saklı tutulmuştur. Katılımcıların görüşlerinden alıntılar yapılırken şu kodlama sistemi yapılmıştır. Ö; öğretmen olduğunu ifade etmektedir. Örneğin (Ö1) kodu, birinci öğretmeni ifade etmektedir.

\section{Veri Toplama Araçları}

Araştırmada nitel veri toplama aracı olarak yarı yapılandırılmış görüşme formu kullanılmıştır: Karasar'a göre (2005) bireysel görüşmeler, görüşmeci ile cevaplayan yani görüşme yapılan birey haricinde başka kimsenin görüşmede bulunmadığı türdedir. Bu görüşme türünde daha çok kişiye özel bilgilere ulaşılır. Araştırmada katılımcıların kurumlarında yaşadıkları sorunlara ilişkin görüşlerini almak amacıyla açık uçlu sorulara dayanan yarı yapılandırılmış form hazırlanmıştır. Görüşme soruları ile ilgili uzman görüşü alınarak içerik geçerliliği sağlanmıştır. Uzman görüşü alınan kişiler bir öğretim üyesi ve Bilim ve Sanat Merkezinde görev yapan iki ögretmendir. Ayrıca konuyla ilgili literatür taraması yapılmıştır.

\section{Verilerin Analizi}

Araştırmanın verileri içerik analizi ile çözümlenmiştir. Fox’a göre (1969) içerik analizi, sözel ve yazılı verilerin belirli bir problem veya amaç bakımından sınıflandırılması, belirli değişken veya kavramların ölçülmesi ve bunlardan belirli bir anlam çıkarılması için taranarak kategorilere ayrılmasıdır (Yalçın ve diğerleri, 2009, s.3). İçerik analizinde temel amaç, toplanan verileri açıklayabilecek kavramlara ve ilişkilere ulaşmaktır. Nitel araştırma verileri dört aşamada analiz edilir: verilerin kodlanması, temaların bulunması, kodların ve temaların düzenlenmesi, bulguların tanımlanması ve yorumlanması (Yıldırım ve Şimşek, 2013). 
$\mathrm{Bu}$ nedenle, araştırma verilerinin çözümlenmesi sürecinde öğretmenlerin verdikleri yanıtlar, araştırma amacına göre kodlanmıştır. Verilerden hareketle, kodların benzerlik ve farklılıkları, birbiriyle ilişkili olmaları dikkate alınarak kategoriler oluşturulmuş ve her bir öğretmenin görüşü, orijinal formu ve anlamı bozulmadan bu kategorilere yerleştirilmiştir. Analiz birimi olarak cümleler kullanılmıştır. Nitel verilerin çözümlenmesi betimsel analizlere (doğrudan alıntılara) uygun olarak yapılmıştır. Veriler, genel ve alt kategorilere göre düzenlenmiş ve işlenmesi için kavramsal bir yapı oluşturulmuştur. Daha sonra, her bir kategorinin hangi sıklıkla tekrar ettiği (frekansı) bulunmuştur. Frekans değerleri aynı zamanda yüzde olarak da verilmiştir. Böylece, nitel veriler nicelleştirilmiştir. Nitel verilerin nicelleştirilmesindeki temel amaç; güvenirliği arttırmak, yanlılığı azaltmak ve kategoriler arasında karşılaştırmalar yapmaktır (Yıldırım ve Şimşek, 2013). Sorulara öğretmenlerin verdikleri cevaplar ayrı olarak değerlendirilmiştir. Buradaki amaç cevaplar arasında kıyaslama yapılabilmesini sağlamaktır. Verilerin analizinde, toplamda ne kadar görüş ifade edildiğinin görülmesi açısından toplam frekanslar verilmiştir. Çalışmanın güvenilirliğini arttırmak amacıyla bir uzmanın çözümlemeleri dikkate alınmış ve ortak noktalar belirlenmiştir.

\section{Bulgular}

Araştırmanın bulgularında öncelikle araştırmanın amacı doğrultusunda öğretmenlerin yaşadıkları sorunlara yer verilirken daha sonra bu sorunlara ilişkin öğretmenlerin çözüm önerileri yer almaktadir.

\section{1. Öğretmenlerin Çalıştıkları Merkezde Yaşadıkları Sorunlar Hakkındaki Görüşleri} Görüşleri

\section{1. Öğretmenlerin Çalış̧ıkları Merkezde Yaşadıkları Kişisel Sorunlar Hakkındaki}

Bu probleme yanıt bulabilmek amacıyla öğretmenlerin çalıştıkları okulda yaşadıkları kişisel sorunlara ilişkin görüşleri ile ilgili frekans ve \% dağ 1 lımı belirlenmiştir. Tablo 1 'de elde edilen veriler görülmektedir.

Tablo 1: Öğretmenlerin Çalıştıkları Merkezle İlgili Kişisel Sorunlarına İlişkin Frekans ve Yüzde Dağ 11 imı

\begin{tabular}{lll}
\hline Kişisel Sorunlar & F & \% \\
\hline 1)Çalışma saatlerinin uygun olmaması & 20 & 66,6 \\
\hline 2) Velilerle iletişim sorunu yaşama & 17 & 56,6 \\
\hline 3) Sınıfların fiziki donanım eksikliği & 16 & 53,3 \\
\hline 4) Öğrencilerin ilgisiz olması & 13 & 43,3 \\
\hline 5) Kurumdaki sınıfların yetersizliği & 12 & 40,0 \\
\hline $\begin{array}{l}\text { 6) Bilsem öğretmenlerinin özlük hakları ve } \\
\text { kadro sıkıntıları }\end{array}$ & 10 & 33,3 \\
\hline
\end{tabular}

Tablo 1'de görüldüğü gibi genel olarak öğretmenlerin çalıştıkları okulda yaşadıkları kişisel sorunlar yorumlanırsa \% 66,6 ile çalışma saatlerinin uygun olmaması ilk sırada yer almaktadır. Araştırmaya katılan 30 öğretmenden 20 tanesi bu sorunu yaşadıklarını ifade etmiştir. Katılımcıların bu konudaki görüşleri aşağıda verilmiştir.

Ö1: Çalışma saatlerinin geç olması tüm aileyi etkiliyor. Hafta sonu olması ve hem sabah hem akşam ders olduğu günler çok yorucu geçiyor. Bilim ve sanat merkezlerinde çalışma saatlerinin öğrencilerin merkeze geleceği saatlere göre hazırlanıyor olması temel sorunlardan biri.

Ö10: Cumartesi günü mesainin olmast ve çalışma saatlerinin hafta içi akşam 20.00 'ye kadar olmast.

Ö16: Çalışma saatleri zaman zaman sorun olabiliyor. Akşam 8'de ders bitiyor. Eve gitmemiz 9'u buluyor. Ailemize vakit ayırmakta zorlaniyoruz. 
Ö19: Örgün eğitimde kurumlarında çalışırken Bilim ve Sanat merkezilerine geçildiğinde uyum sıkıntısı yaşlyoruz. Herkesin derse(okula) gittiği saatte Bilsem ögretmenleri evde, herkesin evde olduğu akşam ve Cumartesi günleri ise biz çalışlyoruz. Bu durum hayatımızı planlarken sorunlar yaratabiliyor.

2. olarak \% 56,6 ile velilerle iletişim sorunu yaşama gelmektedir. 30 öğretmenden 17 tanesi Bilim ve Sanat Merkezinde görev yaptıkları sürede velilerle bir takım iletişim sorunları yaşadığını ifade etmiştir. Katılımcıların açıklamalarından bazıları aşağıda verilmiştir.

Ö4: Velilerin özel yetenekli çocuğundan ve BİLSEM'den beklentisinin gerçek diş1 olması bu sebeple yıpratıcı olması. Alan uzmanı gibi davranıp size işinizi ögretmeye çalışabiliyorlar. Çocukları değil de özel yetenekli olan kendileri gibi bir yaklaşım ve tavır takınabiliyorlar.

Ö7: Veliler genel anlamda eğitim-ögretim alanına bilerek veya bilmeyerek fazlasıyla dâhil oluyorlar. Her kurumda olduğu gibi velilerle iletişim sorunlar yaşanıyor. Çocuklarının ögretmeni olduğumuz için çok şanslı olduğumuzu söyleyip psikolojik baskl yapıyorlar. Her zaman ve saatte arlyorlar. Beklentileri yüksek, bazen kurs ögretmeni muamelesi yapıyorlar.

Ö15: Velilerle zaman zaman iletişim sorunlart yaşıyorum. Veliler, BILLSEM'de yapılan etkinlikleri evde yaparken çocukların yerine kendileri yapıyor. Çocukları biraz daha bağımsız bırakmaları gerekiyor. Bunu yapmalarına olumsuz yanıt verdiğim halde anlatamıyorum.

Ö23:Veliler BILLSEM'de sistemi tam olarak anlamamasına rağmen eğitim öğretim sürecine müdahil olmaya çalışıyor. Kendini üstün gören egosu tavan yapmış bazı velilerle karşılaşıyorum. Ben çocuğumu sizden daha iyi tanıyorum diye düşünen bazı veliler, ögretmenlerin önerilerini dikkate almiyor, dinlemiyor.

3. olarak \% 53,3 ile sınıfların fiziki donanım eksikliği gelmektedir. 30 öğretmenden 16 tanesi sınıflarında fiziki donanım olarak birçok eksiklik yaşadığını ifade etmiştir. Katılımcıların açıklamalarından bazıları aşağıda verilmiştir.

Ö4: Bina ileriye yönelik tasarlanmamış o günün şartları dikkate alınmış olduğundan derslikler hem sayıca hem de nitelik olarak yetersiz. Sinfflarda malzeme yetersizliği var. Malzemelere kolay ulaşamiyoruz ve kendimiz internetten sipariş etme yoluna gidiyoruz.

Ö7: Çocuklarımızın öğrenme ve kendini keşfetme yolculuğunda idare ve ögretmen kadrosu kadar, çalışmaların yapıldığı sınıf ortamının her branşın ruhuna göre düzenlenmiş olması gerekiyor. Bu anlamda sinıflarımızda donanım olarak eksiklikler yaşıyoruz.

Ö27: Alanımızla ilgili bazı sarf ve demirbaş malzemelerde eksikliklerimiz bulunmaktadır. Çalışma koşulları olarak sinıfimda yeterli malzeme ve fiziki imkânlar yoktur. Sinıflar ve merkez yeterince donanımlı değil.

4. olarak \% 43,3 ile öğrencilerin ilgisiz olması gelmektedir. 30 öğretmenden 13 tanesi öğrencilerin BİLSEM'e ve derslere ilgisiz olduklarını ifade etmiştir. Katılımcıların görüşlerinden bazıları aşağıda verilmiştir.

Ö1: Alanımla ilgili matematiğe karşı öğrencilerin ilgilerinin olmadığını düşünüyorum. Öğrenciler BILLSEM'de derslere karşı ilgisiz oldukları için zaman zaman devamsızlık da yapıyorlar. Bu nedenle kopukluklar yaşanıyor.

Ö6: Öğrenciler ilgisiz. Kendilerini her şeyi biliyor olarak görüyorlar ama bilgi açısından bazıları gerçekten yetersiz. Yapılan etkinliklere ilgi göstermiyorlar. Ailelerin zorlamasıyla geliyor bazılart.

Ö12: Ortaokuldaki ögrrencilerde genel bir isteksizlik var. Sorduğumda BILLSEM'e sadece kaydımı silinmesin diye geliyorum diyorlar. 
5. olarak \% 40 ile kurumdaki sınıfların yetersizliği gelmektedir. 30 öğretmenden 12 tanesi öğrencilerin BİLSEM'e ve derslere ilgisiz olduklarını ifade etmiştir. Katılımcıların görüşlerinden bazıları aşağıda verilmiştir.

Ö5: Merkezimizde sinıf kapasitesi ve öğrenci sayısı ters orantılı olup hareket alanım sinırlıdır. Öğrenci sayısının bina potansiyeline paralel olmayışı, grup sayılarının fazla olması, etkinliklerdeki yoğun çalışma, enerjimin son saatlerde zorlanmasına sebep olmakta ve ağır gelmektedir.

Ö10: Rehber öğretmenler olarak veli eğitim ve etkinliklerinde kullanabileceğimiz bir salon olmayışından dolayı öğretmenler odasını kullanıyoruz ve bu bazen ögretmenleri rahatsız ediyor.

Ö23: Merkez binası diğer okullar gibi yapıldığından ihtiyacı karşılamıyor. Sınıf sayısı yetersiz kalıyor. Bazı öğretmen arkadaşlarımızın kendine ait bir sınıfi yok mesela.

Son olarak \% 33,3 ile BİLSEM öğretmenlerinin özlük hakları ve kadro sıkıntıları gelmektedir. 30 öğretmenden 10 tanesi özlük hakları ile ilgili sorunlar bulunduğunu belirtmiştir. Katılımcıların açıklamalarından bazıları aşağıda verilmiştir.

Ö16: Özlük haklarımızla ilgili sorunlar var. Örneğin BILLSEM'de çalıştığımız halde il dışına tayin isteyeceğimizde farklı şehirdeki BILLSEM'i tercih edemiyoruz. Normal okullart tercih etmek zorunda kaliyoruz.

Ö24: BILLSEM öğretmenlerinin statüsünün net olarak ortaya konmasl gerekmektedir. Öğretmenler aynen üniversite ögretim elemanları gibi farklı bir konumda olmalıdır. Verilecek özlük hakları ile alacakları ek ders ücretleri, girecekleri ders saatleriyle kafaların meşgul etmemelidirler ki yeni yeni fikirler, projeler vb. üretebilsinler. Hatta BILSEM'lerin çoğunda kadrolu ögretmen sayısı az olduğundan çalışmalar istenilen düzeyde olmamaktadır.

Katılımcılara göre Bilim ve Sanat Merkezlerinde öğretmenlerin en çok yaşadıkları kişisel sorun çalışma saatlerinin uygun olmamasıdır. BİLSEM'lerde derslerin hafta içi akşam ve cumartesi günleri olması hem öğretmenleri hem de öğrencileri olumsuz etkilemektedir. Öğretmenler velilerle çeşitli iletişim sorunları yaşamaktadır. Bilim ve Sanat Merkezlerinde bazı öğretmenlerin kendine ait bir sınıfi yoktur. Mevcut sınıflarda da fiziki donanım olarak birçok eksiklik bulunmaktadır. Öğretmenlere göre BİLSEM öğrencileri derslere ve yapılan etkinliklere karşı ilgisiz davranmaktadır. BİLSEM'de çalışan öğretmenlerin özlük hakları, norm kadro ve atama ile ilgili sorunları bulunmaktadır.

\section{Görüşleri}

1.2. Öğretmenlerin Çalıştıkları Merkezde Yaşadıkları Eğitsel Sorunlar Hakkındaki

$\mathrm{Bu}$ probleme yanıt bulabilmek amacıyla öğretmenlerin çalıştıkları merkezde yaşadıkları eğitsel sorunlara ilişkin görüşleri ile ilgili frekans ve \% dağılımı belirlenmiştir. Tablo 2.'de elde edilen veriler görülmektedir.

Tablo 2.'ye bakıldığında genel olarak öğretmenlerin çalıştıkları merkezde yaşadıkları eğitsel sorunlar yorumlanırsa \% 86,6 ile araç gereç ve materyal eksikliği ilk sırada yer almaktadır. Araştırmaya katılan 30 öğretmenden 26 tanesi bu sorunu yaşadıklarını ifade etmiştir. Katılımcıların bu konudaki görüşleri aşağıda verilmiştir.

Ö1: Temel araç gereçler bile eksik ya da çok eski. Teknolojik aletler yok, olanlar da bozuk ve eski. Sira masa sandalye yine yok ya da çok eski. Yapılacak etkinlikler için yeterli malzeme bulunmamaktadır. Böyle bir kurumda ögrencilerin deney yapmalarına olanaklar sağlanmal ama maalesef yeteri kadar fiziksel donanıma sahip değiliz. 
Ö7: Sinıflarımız materyal araç gereç anlamında an itibarıyla oldukça yetersiz. Branşımızda laboratuvarımızın olmaması büyük bir eksiklik. Ayrıca dil öğretimi için kelime oyunları vb. materyallere ihtiyacımız bulunmaktadır.

Tablo 2: Öğretmenlerin Çalıştıkları Merkezle İlgili Eğitsel Sorunlarına İlişkin Frekans ve Yüzde Dağılımı

\begin{tabular}{lcl}
\hline Eğitsel Sorunlar & F & \% \\
\hline 1) Araç gereç ve materyal eksikliği & 26 & 86,6 \\
\hline $\begin{array}{l}\text { 2) Çerçeve programdaki etkinliklerin } \\
\text { işlevsiz olması }\end{array}$ & 24 & 80,0 \\
\hline 3) Öğrencilerin isteksiz ve yorgun olması & 23 & 76,6 \\
\hline 4) Öğrencilerin devamsızlık yapması & 20 & 66,6 \\
\hline 5) Velilerin aşırı beklenti içinde olmaları & 17 & 56,6 \\
\hline $\begin{array}{l}\text { 6) Teknolojik destek ve internet altyapı } \\
\text { eksikliği }\end{array}$ & 14 & 46,6 \\
\hline 7)Gruplarda öğrenci mevcudunun fazlalığı & 13 & 43,3 \\
\hline 8)Öğrencilerde davranış bozukluğu & 13 & 43,3 \\
\hline 9)Öğrencilerin alan seçimi ile ilgili sorunlar & 10 & 33,3 \\
\hline 10) Teneffüs süresinin kısa olması & 9 & 30,0 \\
\hline
\end{tabular}

Ö13: BİLSEM coğrafya programı daha çok deneysel ă̆ırlıkl ancak elimizdeki deney malzemeleri sıkıntılı ve az sayıdadır. Örneğin sınıfa ait bir mikroskop yok. Çoğu deney için kimyasal Malzeme lazım ancak kurumda araç gereç ve malzeme ile ilgili yardım alamıyoruz. Malzemelerin Hepsini kendim karşıladım ve karşıllyorum.

Ö17: Donanım, araç gereç ile ilgili bazı eksiklikler vardır. Örneğin seramik fırını, seramik masası, heykel atölyesi, çark, ışıklı masa, bilgisayarlar, boyalar, firçalar vb. birçok eksiğimiz var. Kurumuтиzun üstün-özel yetenekli ögrencilere yönelik materyal ihtiyacı oldukça fazladır.

2. olarak \% 80 ile çerçeve programdaki etkinliklerin işlevsiz olması gelmektedir. 30 öğretmenden 24 tanesi etkinliklerin uygulanmasında sorunlar yaşadıklarını ifade etmiştir. Katılımcıların açıklamalarından bazıları aşağıda verilmiştir.

Ö1: Çoğu etkinlik 80 dakika üzerinden hesaplanarak hazırlanmış. Ancak bizim 40 dakikamız var. Etkinlikler düzenli değil, içerisinde yanlışları çok fazla, sınıf seviyelerine göre düzenli ayrilmamış ve tekrar eden etkinlikler var. Çerçeve programının içinde yer alan etkinliklerin hem içerik hem de uygulanabilirlik açısından yeterli olmadiğın bu nedenle yeniden gözden geçirilmesi gerektiğini düşünüyorum.

Ö4: Çerçeve program bir öneri niteliğinde eksikliklerin giderilmesi ve özellikle BILLSEM'e ilk başlayan ögretmenlerin yararlanabileceği bir program. Bu program etkinlik örneklerinin bir araya getirilmesi ile oluşturulduğu için konular arası geçişlerde kopukluklar var. Etkinliklerin basitten karmaşı̆̆a, kolaydan zora gibi sıralanmasında sılkntılar var. Etkinlikleri yetiştirmek ve kazanımları tam gerçekleştirmek de fedakârlık gerekiyor. Öğrenci sayısından dolayı yetiştirmek zor oluyor. Ayrıca uygun olmayan etkinlik ve etkinlik cümleleri ile karşılaşıyoruz, bunları bildiriyoruz ancak ertesi yıl da aynı etkinlik değişstirilmiyor.

Ö14: Programdaki bazı konuların öğrenciler için sıkıcı olduğunu düşünüyorum. Öğrencilerin ilgisini çekecek daha iyi etkinlikler hazırlanmalı. Bazı konular da öğrencilerin seviyesinin üzerinde. Öğrencilerin üstün yetenekli olduğu düşünülerek çok fazla seviyelerinin üstünde etkinlikler olabiliyor. Bazı etkinliklerin de tam tersi seviyesi düşük ve çocuklara çok uygun değil. Etkinlikler özen gösterilmeden kes kopyala yapıştır olarak hazırlanmış gibi. 
Ö20: Çerçeve programda Bilsem eğitiminin mantığında bireysel eğitim olduğu için ĕger ögrencilerimizin hazırbulunuşluk düzeyine uygun olmayan basit etkinliklerin uygulanması ögrencilerin slkılmasina, dersten bilsem den kopmalarına sebep olur. Bu etkinliklerden bazlları uygulanırken öğrencilerin isteksiz olduklarını sıkıldıklarını gözlüyoruz. Tüm öğrenciler eğlenceli dersi tercih ediyor. Hiçbir ögrenci fotokopi ve klasik dersi sevmiyor.

3. olarak \% 76,6 ile öğrencilerin isteksiz ve yorgun olması gelmektedir. 30 öğretmenden 23 tanesi öğrencilerin BİLSEM'e yorgun geldiklerini ve isteksiz davrandıklarını dile getirmiştir. Katılımcıların açıklamalarından bazıları aşağıda verilmiştir.

Ö3: Öğrencilerde ilgisizlik, okuldan sonra yorgunluk veya bıkmışlık, verilen görevi yerine getirememe boş vermişlik var. BİLSEM'de üretim noktasinda isteksizler. Proje üretme konusunda hazır fikir bekliyorlar. Yeterince araştırma yapmıyorlar.

Ö6: Yaptıklarl etkinliklere yeteri önemi göstermemekte ve bir an önce dersi bitirip gitme derdinde olmaktadırlar. Proje ögrencilerinin proje yapmalar istenmekte fakat öğrenciler bunun yerine bu kurumları dershane mantığında dersi daha iyi öğrenebilecekleri yerler ya da stres atma ortamı olarak görmektedirler. Zaten buraya hafta içi okuldan sonra geldikleri için çok yorgun ve tükenmiş olarak geliyorlar.

Ö7: Yoğun bir okul programından sonra buraya geldiklerinde aç yorgun olabiliyorlar küçük gruplarda öğrenme isteği oldukça fazla fakat yaş seviyesi arttıkça bu temponun getirdiği yorgunluk, bıkkınlık, ergenlik motivasyonlarını azaltıyor. öğrencilerdeki motivasyon düşüklüğü, Aşırı ilgi beklentisi, etkinlikleri ciddiye almama, yorgun olmalyorgun tavirlar sergileme ögrrencilerle ilgili karşılaş̧tı̆̆ımız sorunlardır.

Ö20: Bazı ögrenciler etkinliklere, projelere katılmada istekli olmuyorlar. Okuldan çıkıp BILLSEM'e geliyorlar. BILLSEM'den akşam saat 8'de çıkıp eve gitmeleri sebebiyle yorgun oluyorlar. Çocuklarımı okulla birlikte BİLSEM'i götürdüklerinden yorulma ve bikkınlık gibi durumlarla karşılaşabiliyoruz.

4. olarak \% 66,6 ile öğrencilerin devamsızlık yapması gelmektedir. 30 öğretmenden 20 tanesi öğrencilerin BİLSEM'e devamsızlık yaptıklarını ifade etmiştir. Katılımcıların açıklamalarından bazıları aşağıda verilmiştir.

Ö2: BILLSEM'e devamla ilgili sorunlar oluyor. Öğrenciler sık sık devamsızlık yapıyorlar. Özellikle sınav hazırlık zamanlarında yaşanıyor. Devamsızlık takipleri konusunda da aksaklıklar görüyoruz.

Ö9: Özellikle 8. Sinıf ve 12. Sinı ögrencilerimizde sinav hazırlıklarından dolayı devamsızlık problemi oluşuyor. Okullarındaki yoğun programlarından dolayı Proje hazırlamada yeterli zaman ayıramamaktadirlar.

Ö18: Devamsız olan ögrenciler mevcut. Bunun yanında ailesinin zorlamasl ile gelen ögrenciler var. Özellikle lise öğrencilerinde devamsızlık problemi yaşıyoruz. BİLSEM'de sınıf düzeyi arttıkça devamsızlıklar artıyor. Öğrenciler sorumluluklarını yerine getirmede problemler var.

Ö22: Öğrencilerde devamsızlık sıkıntısı oluyor. Devamsızlık yapanların çoğu ulaşım, okul saatleri vb. gibi sebeplerden dolayı gelemiyor. Bazı ögrencilerimiz de diğer ilçelerden geldikleri için, özellikle Cumartesi günü sabaha derslerine geç kalabilmektedir.

5. olarak \% 56,6 ile velilerin aşırı beklenti içinde olması gelmektedir. 30 öğretmenden 17 tanesi velilerin öğrenci ve öğretmenlerden yüksek beklentileri olduğunu dile getirmiştir. Katılımcıların açıklamalarından bazıları aşağıda verilmiştir.

Ö4: Velilerin istekleri ve beklentileri çok yüksek ve gerçeğe dayanmıyor. Çocuğu fikir üretmediği ve araştırma yapmadĭ̆ı halde veliler ögretmen yapımı projeler bekliyor. Yapıcı olmak 
yerine çoğu zaman mükemmeliyetçi bir bakış açıslyla yaklaşıp sadece eleştiriyorlar. Çocuklardan potansiyelinden fazlasinı bekliyorlar.

Ö8: Velilerde çocuklarla ilgili yüksek beklentiler oluşmaktadır. Bu da zaman zaman sorun yaratmaktadır. Öğrencisinin üstün zekâlı olduğuna aşırı odaklanmaktadır.

Ö11: BILSEM'de veliler aşırı talepkar ve sabırsızlar. Çocuklarının bir an önce projelere dâhil edilmesini bekliyorlar. Çocuklarını olduklarından fazla gözlerimde büyütüyor. Veliler Sadece sonuç odaklı düşünüyorlar. Sadece çocukları TÜBİTAK projelerinde derece alsın istiyorlar. Süreçte yapmaları gerekenleri yapmıyorlar.

Ö28: Bazl velilerimiz kurumun işleyişini bilmediklerinden dolayl, burayı normal bir okul ya da kurs gibi düşünebilmektedirler. Ayrıca ögrencilerinin buraya hemen girince bir proje yapmasını beklemektedirler. Bu süreçlerin uzun bir hazırlık gerektirdiğini fark edememektedirler. Tüm veliler ögrencilerini Einstein sanıyor. Dolayısıyla da gereğinden çok fazla beklenti içine giriyorlar.

6. olarak \% 46,6 ile teknolojik destek ve internet altyap1 eksikliği gelmektedir. 30 öğretmenden 14 tanesi BILSEM'de teknolojik destek ve internet altyapısının eksikliğinden kaynaklı sorunlar yaşadığını dile getirmiştir. Katılımcıların açıklamalarından bazıları aşağıda verilmiştir.

Ö4: Alan ile ilgili ücretli bilgisayar yazılımlarını elde edip ve kullanamıyoruz. Bu sebeple dersler kalem kâğıda indirgeniyor. Teknoloji desteği çok yetersiz. Kurumda internet alt yapısı istenilen düzeyde değil. Dersliklerde ögrencilerin bireysel araştırma yapmalarına imkân taniyacak bilgisayarlar yok varsa bile yetersiz.

Ö6: Öğrencilerle yapılan proje incelemeleri esnasında ya da faydalanacağımız videoları seyretmekte problem yaşanmaktadır. Bu tür etkinlikler genelde Youtube kanalindan yayınlanmakta ama kurumumuzdaki MEB filtresi nedeniyle bunlara ulaşllamamaktadır. Bilim sanat merkezine gelirken çok donanımlı bir yerdir diye düşünmüş̧üm. Fakat her sınıfta internet bile yok.

Ö15: Özellikle öğrenciye ders esnasında anında dönüt vermek için internet bağlantısına ihtiyacımız oluyor. Ancak internet altyapısı yetersiz. BİLSEM'de sinfflarda akill tahta olmaması önemli bir eksiklik. Fotokopi çekmekte bile sorun yaşlyoruz. Bilgisayar, yazıcı ve kâğıt gibi birçok malzeme yetersiz.

Ö19: Sinıflarda interneti verimli kullanamıyoruz. Online oyunlar ve quizler ile dil ögretimi eğlenceli hale getirilebilir ancak MEB engeli çoğu yararlı siteyi açmamızı engelliyor.

7. olarak \% 43,3 ile gruplarda öğrenci mevcudunun fazlalığ gelmektedir. 30 öğretmenden 13 tanesi öğrenci mevcudunun arttı̆̆ını ve sınıfların kalabalıklaştığını dile getirmiştir. Katılımcıların açıklamalarından bazıları aşağıda verilmiştir.

Ö3: Görev yaptı̆̆ım kurumdaki ögrrenci gruplarının ideal sayının üzerine çıkması sınıf yönetimi, rehberlik ve sınıf fiziki koşullarını zor hale getirmektedir. Aynı zamanda özel eğitimin amacına da ters düşmektedir. Öğrenci sayısı çok fazla olduğu için ögrrencileri oturtacak sıra bulmakta zorlandı̆̆ım gruplar oluyor.

Ö5: Merkezimizde öğrenci sayısı 900'ü geçiyor. Etkinlikleri yaparken sinıfinı alanı ve öğrenci sayısına göre bazı etkinliklerde zorlanmaktayım. Etkinliğin yapılabileceği alan ile sinıfin kapasitesi ve öğrenci sayıları uyumlu değil. Sinıfim küçük öğrenci sayısına göre yetersiz hareket alanı kisitlıdır. Siniflar 68 kişilik gruba uygundur.

Ö30: Etkinlikleri uygulamada sıkıntı yaşıyoruz. Çünkü öğrenci sayısının fazlalı̆̆ı, grupların kalabalık oluşu, uygulamada birebir iletişimden ziyade, sınıfa hitap durumuna dönüşüyor. 40 dakikalık sürede kendisine söz hakkı yeterince düşmediğini ifade eden ögrenciler var bazı ögrencilerimiz müsait olduğu durumlarda bir sonraki grupla devam etme talebinde bulunuyorlar. 
Daha sonra yine \% 43,3 ile öğrencilerde davranış bozukluğu sorunu gelmektedir. 30 öğretmenden 13 tanesi öğrencilerde birtakım davranış bozuklukları gözlemlediklerini dile getirmiştir. Katılımcıların açıklamalarından bazıları aşağıda verilmiştir.

Ö5: BILLSEM kültürünü yerleştirme aşamasında öğrencilerde davranış problemleri ile karşılaşılmaktadır. Üstün yetenekli bazı ögrencilerde davranış problemleri daha sık görülebiliyor. Öğrenci sayılarının fazla olması birebir ilgilenmeyi sınırlı hale getiriyor. Davranış eğitimi ve problemlerin çözümü için zaman yetersizleşiyor, dikkat dağlliyor.

Ö15: BİLSEM'e gelen ögrencilerde kendini beğenmişlik ve kendini üstün görme gibi sorunlarla karşılaşıyorum. Özellikle akşam gruplarında özel okuldan gelen ögrrencilerde davranış problemleri var.

Ö23: Okullarında en başarılı öğrenci iken merkezde Kendinden daha başarılı öğrenciler ile karşılaşan bazı ögrencilerin bocalaması, gelmek istememesi, kendini göstermek için yaramazlık vs. yollara başvurması. Bazı ögrencilerin aşırı derecede bencil yetiştirilmiş olması nedeniyle arkadaşlarına ve ögretmenlerine saygı göstermiyor. Özellikle kolej ögrencilerinin eşyalara zarar verdiğini, dikkat etmediğini görüyoruz.

Sonra \% 33,3 ile öğrencilerin alan seçimi ile ilgili sorunlar gelmektedir. 30 öğretmenden 10 tanesi BİLSEM'de öğrencilerin alanlara ayrılması sürecinde sorunlar olduğunu belirtmiştir. Katılımcıların açıklamalarından bazıları aşağıda verilmiştir.

Ö2: Öğrencilerin alanlara seçilmesi sürecinin uzun olması da bir sorun olarak karşımıza çılkyor. Bu süreç daha kısa olmalı.

Ö4: Aile baskısıyla seçilmiş alana devam etmede sıkıntı oluyor. Öğrenci o alanda proje üretmede isteksizlik yaşıyor. Aynı zamanda o alanda ön bilgisi eksik olduğundan yetersiz kallyor.

Ö7: Öğrencinin bütün branşlarda iyi olup bir alanda pasif olması onun yetersiz eksik olduğu anlamına gelmez. Ailelerin bu bakış açısıyla çocuklarda her alanda iyi olmalıyım telaşı var. Bundan dolayı çok iyi olmadığ bir alana yönelebiliyor. Sonra kendilerini gösteremediklerinde duygusal anlamda inciniyorlar.

Son olarak \% 30 ile teneffüs süresinin k1sa olması gelmektedir. 30 öğretmenden 9 tanesi BİLSEM'de teneffüs sürelerinin kısa olduğunu belirtmiştir. Katılımcıların açıklamalarından bazıları aşağ 1 da verilmiştir.

Ö18: BILLSEM'de dersler akşam olduğundan teneffüs süreleri çok kısa tutuluyor. 5 dakikada çocuklar bir sınıftan diğer sinıfa ancak yetişiyor zaten. Dinlenecek zaman hiç kalmıyor. Teneffüs ve dinlenme sürelerinin daha ideal hale getirilmesi gerekmektedir.

Ö22: Teneffüs süresi az olduğu için hem öğretmenlerin hem de ögrrencilerin dinlenme firsatı olmuyor. Öğrenciler okuldan buraya yetişmeye çalışlyorlar. Burada da bir dersten diğerine koşturuyorlar. Akşam çok geç çıkmasınlar diye teneffüsler maalesef kısa oluyor.

Öğretmenler eğitsel sorunlarına bakıldığı zaman çalıştıkları merkezde en çok araç-gereç ve materyal eksikliği yaşamaktadır. Sınıflarda teknolojik destek ve internet altyapısı yetersizdir. Bunun yanında Bilim ve Sanat Merkezlerinin çerçeve programlarında yer alan etkinlikler içerik bakımından sorunlar içermektedir. Bazı etkinlikler öğrencilerin sıkılmasına neden olmaktadır. Öğretmenlere göre öğrenciler okuldan çıkıp yorgun bir şekilde BİLSEM'e geldikleri için derslere karşı isteksiz davranmaktadır. Teneffüs süreleri de kısa olduğu için dinlenmeye vakitleri yoktur. Öğrencilerde farklı şekillerde davranış problemleri görülmektedir. Zaman zaman devamsızlık yapmaktadırlar. Velilerin çocuklarından ve öğretmenlerden aşırı beklenti içine girdiği görülmektedir. Bilim ve Sanat Merkezlerinde öğrencilerin alanlara ayrılması sürecinde ailelerin müdahale etmesi nedeniyle 
birtakım sorunlar yaşanmaktadır. Son yıllarda BİLSEM'lerde öğrenci sayıları hızla artmaktadır. Sınıf mevcutları BİLSEM yönergesine göre olması gerekenden çok yüksektir.

\section{Görüşleri}

\section{3. Öğretmenlerin Çalıştıkları Merkezde Yaşadıkları Yönetsel Sorunlar Hakkındaki}

$\mathrm{Bu}$ probleme yanıt bulabilmek amacıyla öğretmenlerin çalıştıkları merkezde yaşadıkları yönetsel sorunlara ilişkin görüşleri ile ilgili frekans ve \% dağılımı belirlenmiştir. Tablo 3’te elde edilen veriler görülmektedir.

Tablo 3: Öğretmenlerin Çalıştıkları Merkezle İlgili Yönetsel Sorunlarına İlişkin Frekans ve Yüzde Dağılımı

\begin{tabular}{lcc}
\hline Yönetsel Sorunlar & F & \% \\
\hline 1)Yönetici ve öğretmenler arasında iletişim sorunu & 16 & 53,3 \\
\hline 2)Öğrenci gruplarının oluşturulması ile ilgili sıkıntılar & 12 & 40,0 \\
\hline 3) Yöneticilerin sonuç odaklı düşünmesi & 11 & 36,6 \\
\hline 4)Yöneticilerin öğretmenlere karşı adaletli olmaması & 10 & 33,3 \\
\hline 5) Temizlik sorunu & 7 & 23,3 \\
\hline
\end{tabular}

Tablo 3'te görüldüğü gibi genel olarak öğretmenlerin çalıştıkları merkezde yaşadıkları yönetsel sorunlar yorumlanırsa \% 53,3 ile yönetici ve öğretmenler arasında iletişim sorunu ilk sırada yer almaktadır. Araştırmaya katılan 30 öğretmenden 16 tanesi bu sorunu yaşadıklarını ifade etmiştir. Katılımcılardan bazılarının bu konudaki görüşleri aşağıda verilmiştir.

Ö5: Çalışma saatlerinin uygun olmamasından kaynaklandiğını düşündüğüm iletişimsizlik sorunu var. İdare ile yüz yüze iletişsim firsatı bulamıyoruz. İdareciler arasında da bazı iletişim problemleri var ve bazı konularda aralarında fikir ayrılıkları oluyor.

Ö7: Öğretmenlerin giriş,- çıkış, saatlerindeki farklılıklardan dolayı iletişim sıkıntısı hem idareyle hem de kurumdaki diğer çalışanlarla yaşanmaktadır. Yoğun olduğumuz için idareyle görüşme firsatımız olmuyor. Bu yüzden iletişsimimiz eksik kalıyor. Böylece güncel idari konuların takibi de zorlaşıyor.

Ö11: İdari sorunlar olarak müdür ve müdür yardımcısını birbirinden ayırarak düşünürsek müdür yardımcılarının müdüre yenilikçilik açısından ayak uyduramadıklarını düşünüyorum. $O$ yüzden kendilerini değiştirmeleri gerekir. Burası proje tabanl olmasına răgmen hala ders içeriklerine takılıyorlar.

Ö29: Bazı yöneticilerimize sorunlarımızı anlatmada sıkıntı yaşıyoruz. Yapmak istediğimiz bazı şeyleri yapamıyoruz. Her şeye hayır diyorlar. Bazı idareciler kurumu normal bir okul gibi düşünüyor. Ayrıca idarecilerin kendi aralarındaki iletişimsizlik sorunlara yol açıyor.

2. olarak \% 40 ile öğrenci gruplarının oluşturulması ile ilgili sıkıntılar gelmektedir. 30 öğretmenden 12 tanesi BİLSEM'de grupların oluşturulmasında sorunlar olduğunu ifade etmiştir. Katılımcıların açıklamalarından bazıları aşağıda verilmiştir.

Ö1:Farklı sinıf seviyesindeki öğrencilerin aynı grupta olması etkinlik sayısını kısaltıyor ve daraltiyor. 7 ve 8. siniflar bir arada 6 ve 7. siniflar bir arada oluyor. Bu durum sikint yaratiyor.

Ö5: Kayıtlar sonrası sını ögrenci listelerinin belirlenmesi, oturması gecikmektedir. Uyum döneminde oturmuş olması gerekir. Bu oturmadı̆̆ında işimiz zorlaşmaktadır. Veli iletişimi, grup oluşumu ve tanıtımı gecikmektedir. Bu da farklı iletişim sorunlarına neden olmaktadır.

Ö10: Öğrenci ailelerimizin çok farklı sosyo-kültürel ve ekonomik çevrelerden olması nedeniyle, gruplarımız çok heterojendir. Bu durum ögrenciler arası farklllıklara sebep olmaktadır. Bu da grup eğitiminde ögretmen açısından sorun teşkil etmektedir. 
Ö23: Bazı gruplarda yı ̆̆lma olduğundan sınıf saylları çok fazla oluyor. Velilerin istekleri önemsenip ögretmenler görmezden geliniyor. Öğretmenler veliler karşısında zor durumda bırakllıyor. Velilerin özel isteklerinin kabul edilmesi nedeniyle sinıflar kalabalık oluyor.

Sonra \% 36,6 ile yöneticilerin sonuç odaklı düşünmesi gelmektedir. 30 öğretmenden 11 tanesi yöneticilerin kurum başarısını düşünerek sonuç odaklı düşündüğünü belirtmiştir. Katılımcıların açıklamalarından bazıları aşağıda verilmiştir.

Ö8: Yöneticiler projeleri ve yarışmaları nihai hedef olarak görüyor Ve bu konuda psikolojik baskı yapıyorlar. Beklentileri sürekli proje üretmemiz. Ancak bunun için maddi destekleri de yok. Reklam malzemesi olarak kullanılıyor çoğu işimiz.

Ö14: Bilim sanat merkezlerinin kendi aralarındaki rekabet ortamı nedeniyle yöneticilerin kendilerini başarılı ve öncü olmaları konusunda baskı altında hissetmeleri nedeniyle çalışma ortamının giderek rekabetçi bir ortam olmaya doğru gitmesi, öğretmenin yaratıcılı̆̆l ve çalışma azmini etkilediğini düşünüyorum.

Ö23: Merkez müdürlerinin bu ögrenciler hakkında yeterince bilgi sahibi olmadıklarını düşünüyorum. Duygusal açlık çeken, ilgi isteyen ögrrencilere yarış atı muamelesi yapıllyor. Birçok şey ögretmenlerin çabası ile yapıllyor. Yeterince destek verilmiyor. Sürekli bir rekabet ortamı yarış ortamı yaratılmaya çalışıllyor.

Daha sonra \% 33,3 ile yöneticilerin öğretmenlere karş1 adaletli olmaması gelmektedir. 30 öğretmenden 10 tanesi yöneticilerin öğretmenlere bazı konularda eşit davranmadığını belirtmiştir. Katılımcıların açıklamalarından bazıları aşağıda verilmiştir.

Ö4: Bütçe ve kaynak dă̆llımı zaman zaman farklı branşlara dengesiz şekilde oluyor. Kurumda idare tarafindan herkese eşit kaynak ayrılmıyor. Bazı sinıfların ihtiyaçları karşılanırken bazılarına malzeme sağlanmiyor.

Ö23: Sınıf ihtiyaçlarını öğretmenlerin çabası ile gidermeye çalışıyoruz. Öğretmenlerin bazılarının sinıfları donanıp döşenirken bazılarına eski malzemelerin verilmesi bizi üzüyor. Bir sinıftaki eski eşya başla bir sınıfa gidiyor. Sürekli eşyaların yerinin değişiyor.

Son olarak \% 23,3 ile temizlik sorunu gelmektedir. 30 öğretmenden 7 tanesi kurumlarında temizlik sorunu yaşandığını ifade etmiştir. Katılımcıların açıklamalarından bazıları aşağıda verilmiştir.

Ö5: Sinıfların ve lavaboların temizliği konusunda zaman zaman sikıntılar görüyorum. Bilim sanat merkezleri bu konuda örnek olmalıdır. Temizlik konusu daha özenli olmalıdır.

Ö23: Sinıfların çöp kovaları her gün boşaltılması lazım ancak yapılmıyor. Özellikle slcak havalarda sinıfta pis koku yayılıyor. İdarecilerin bunun takibini iyi yapmasi gerekiyor. Tuvaletler de bazen pis kallyor. Velilerde bu konuda şikâyet allyoruz.

Bilim ve Sanat Merkezlerinde yöneticiler kurumun başarılı olması için sonuç odaklı düşünmektedir. $\mathrm{Bu}$ nedenle yöneticiler ile öğretmenler arasında problemler yaşanabilmektedir. Yöneticiler öğretmenlere sunulan olanaklar noktasında eșit davranmamaktadır. Bazı öğretmenlerin sınıfları 3-4 kişilik olurken bazı öğretmenler 15-20 kişilik sınıflarda ders yapmaktadır. Bu durum öğrenci gruplarını dengesiz bir hale getirmektedir. Öğretmenler sınıflarında ve lavabolarda temizlik sorunları yaşamaktadır. 


\section{Önerileri}

\section{2.Öğretmenlerin Bilim ve Sanat Merkezlerinde Yaşadıkları Sorunlarla İlgili Çözüm}

$\mathrm{Bu}$ probleme yanıt bulabilmek amacıyla öğretmenlerin Bilim ve Sanat Merkezlerinde yaşanan sorunlara yönelik çözüm önerileri ile ilgili frekans ve \% dağılımı belirlenmiştir. Tablo 4 'te elde edilen veriler görülmektedir.

Tablo 4: Öğretmenlerin Bilim ve Sanat Merkezlerinde Yaşadıkları Sorunlara Yönelik Çözüm Önerilerine İlişkin Frekans ve Yüzde Dağılımı

\begin{tabular}{llc}
\hline Çözüm Önerileri & F & \% \\
\hline $\begin{array}{l}\text { 1)BİLSEM'lerde çalışma saatleri gündüze } \\
\text { alınmalıdır. }\end{array}$ & 22 & 73,3 \\
\hline $\begin{array}{l}\text { 2)MEB BİLSEM'lere fiziki donanım } \\
\text { konusunda destek sağlamalıdır. }\end{array}$ & 18 & 60,0 \\
\hline $\begin{array}{l}\text { 3)Velilerle iletişim kurularak BİLSEM } \\
\text { hakkında bilgilenmeleri sağlanmalıdır. }\end{array}$ & 16 & 53,3 \\
\hline $\begin{array}{l}\text { 4)Sinıf mevcutları yönetmeliğe uygun şekilde } \\
\text { ayarlanmalıdır. }\end{array}$ & 15 & 50,0 \\
\hline $\begin{array}{l}\text { 5)Öğrencilerin branşlara ayrılma süreçleri } \\
\text { yeniden düzenlenmelidir. }\end{array}$ & 14 & 46,6 \\
\hline $\begin{array}{l}\text { 6)Çerçeve programlar yeniden düzenlenerek } \\
\text { etkinlikler zenginleştirilmelidir. }\end{array}$ & 13 & 43,3 \\
\hline $\begin{array}{l}\text { 7) BİLSEM'lere MEB tarafından daha fazla } \\
\text { ödenek ayrilmalıdır. }\end{array}$ & 13 & 36,6 \\
\hline $\begin{array}{l}\text { 8)BİLSEM'e öğrenci seçim süreçleri yeniden } \\
\text { düzenlenmelidir. }\end{array}$ & 11 & 36,6 \\
\hline 9)Kurum içi iletişim güçlendirilmeli & 11 & 33,3 \\
\hline $\begin{array}{l}\text { 10)Öğrencilerin devamsılık durumu sıkı } \\
\text { takip edilmelidir. }\end{array}$ & 10 & 26,6 \\
\hline $\begin{array}{l}\text { 11) Bilsem öğretmenlerinin özlük hakları } \\
\text { iyileştirilmeli }\end{array}$ & 8 & \\
\hline
\end{tabular}

Tablo 4'e göre, öğretmenlerin çözüm önerileri yorumlanırsa; ilk sırada \% 73,3 ile "BİLSEM'lerde çalışma saatleri gündüze alınmalıdır." önerisi gelmektedir. 30 öğretmenden 22 tanesi bu öneriyi belirtmiştir. Katılımcılardan bazılarının bu konudaki görüşleri aşağıda verilmiştir.

Ö6:Öğrenciler zamanlarının büyük bir oranında bilsem de geçirmeli tam zamanlı Bilsem modeline geçilebilir. Böylece çalışma saatleri akşam saatleri ve hafta sonu olmayacak şekilde düzenlenebilir.

Ö12: Ders saatleri öğrencinin yaş seviyesine uygun olarak öne çekilmeli, özellikle küçük yaş grupları okul ĕgitimlerinin bittiği akşam saatlerine bırakılmamalı okullar bu konuda BİLSEM'lerle işbirliğine gitmeli.

Ö24:Öğrencilerin hem normal okula hem de BILLSE'e devam etmeleri onlar açısından yorucu oluyor. Bu durum bizi de olumsuz etkiliyor. Tam zamanlı eğitimin yararlı olacağını düşünüyorum. Böylece bizler içinde mesai saatleri gündüze çekilebilir. Yapılabilecek program değissiklikleri ile Bilim ve Sanat merkezleri farklı bir statüye alınarak ögrencilerin tam gün burada eğitim almaları să̆lanabilir.

2. olarak \% 60 ile "MEB BİLSEM'lere fiziki donanım konusunda destek sağlamalıdır." gelmektedir. 30 öğretmenden $18^{\prime} \mathrm{i}$ bu öneriyi dile getirmiştir. Katılımcıların açıklamalarından bazıları aşağıda verilmiştir. 
Ö9: BILLSEM'lerde fiziki donanımlar iyileştirilmeli. Verimli bir eğitim için materyaller temin edilmeli ve her ders için laboratuvarlar oluşturulmall. Etkinliklerde kullanılacak malzeme materyal temini de karşılanmall.

Ö14: Derslikler o alana göre düşünülüp tasarlanmamış sonradan o alana göre düzenlenmeye çalışılmış. O yüzden klasik sınıf düzeninden çok öteye geçemiyor. Özel yetenekli bireylerin eğitim alacă̆ı binalar da daha özel tasarlanmal, bina tasarlantrken alanlara göre derslikler yapılandırılmalı. Sonradan değil. Teknolojik alt yapı sağlanması ve materyal anlamında ögretmenin çabasına bırakılmamalı bir standart sağlanmaya çalışılmalı.

Ö20: . Sinıflarda ögrrencilerin araştırma yapabileceği bilgisayar sayısı artırılmalıdır. İnternet bağlantısı güçlendirilmelidir. Materyal araç gereç donanım eksiklikleri üstün özel yetenekli ögrencilerin ihtiyaçlarına göre giderilmelidir.

3. olarak \% 53,3 ile "Velilerle iletişim kurularak BİLSEM hakkında bilgilenmeleri sağlanmalıdır." gelmektedir. 30 öğretmenden 16 bu öneriyi ifade etmiştir. Katılımcıların açıklamalarından bazıları aşağıda verilmiştir.

Ö7: Bazı velilerin özel öğrenci davranışları, ilgi yetenek ve tutumları arasındaki farklılıklar, yetenek alanları gibi alanlarda daha çok bilgilendirilmesi gerektiğini düşünüyorum. Veli ve ögrenci rehberlik birimleri tarafindan düzenli eğitime alınmalı

Ö7: Rehberlik servisi velilere yönelik çalışmalar yapmalı. Zeki olmanın iyi yönetilmeyen bir süreçte insani değerlerle beslenmezse değer olmaktan çıkıp sorun olarak karşımıza çıkabiliyor. Velilerin çocuklarını takip etmelerini anliyorum fakat velilerin sinılar olması gerektiğini düşünüyorum hem eylem hem söylem anlamında. Velilerin fiziki anlamdaki sınırları belirlenmeli.

Ö21: Kurumdaki katılım ve etkinliğe dâhil olmalarının Okul-aile ve ögrenci üçgenindeki sağllklı etkileşimle çözülebileceğini düşünüyorum. Kurumun yapısı ve işleyişi ile ilgili yeni velilere gereken bilgilendirmeler yapılmalıdır. Öğrencilere ve velilerine rehberlik servisi veya uzman kişilerce eğitim verilmelidir.

4. olarak \% 50 ile "Sınıf mevcutları yönetmeliğe uygun şekilde ayarlanmalıdır." gelmektedir. 30 öğretmenden 15 bu öneriyi ifade etmiştir. Katılımcıların açıklamalarından bazıları aşağıda verilmiştir.

Ö1: Öğrenci gruplarının sayısı yönetmelikte belirtildiği gibi olmalıdır. Grup sayıları 8 ögrenciyi geçmemelidir, kalabalık olmamalıdır. Velilerin özel isteklerine göre hareket edilmemelidir.

Ö22: sınıfların kalabalık olmaması için sınıf planlamaları yapılırken öğretmenlerin fikirlerinin alınarak ortak karar verilmesi gerekir. Öğrenci sayısının özel eğitim için makul sayıya indirilmesi gerekir.

Ö25: Gelecek sene aramıza katılacak olan ögrencilerle 70 olan sayımız yaklaşık 100 ögrenciye ulaşacaktır. Şu an için kullandı̆̆ımız alan ögrencilerimiz için yetersiz gelmeye başlayacaktır. Sinıf mevcutlar her yıl artıyor. Yönergedeki sayılara uyulamıyor. Bunun önlenmesi için yeni bina anlamında olabilir, gerekli adımlar atılmalıdır.

5. olarak \% 46,6 ile "Öğrencilerin branşlara ayrılma süreçleri yeniden düzenlenmelidir." gelmektedir. 30 öğretmenden 14 bu öneriyi dile getirmiştir. Katılımcıların açıklamalarından bazıları aşağıda verilmiştir.

Ö5: Öğrenciler daha erken branşlarına ayrllmall. Alanlara seçilme sürecinin daha kısa olmall. Bir de bence ögrencinin ÖYG döneminde en fazla 2 alanda devam etmesi gerekir. 
Ö13: Velilerin alan seçimi konusunda baskılarının ve bazı derslere yığllmaların önüne geçilemiyor. Velilerin alan seçiminde baskısını azaltmak için idare daha kararlı durmalı programlar arası geçişte değerlendirme değiştirilmeli daha çok öğretmenin kararı ve ögrencinin yeteneği etkili olmall.

Ö16: Öğrencinin byf(bireysel yetenekleri fark ettirme programı) süreleri fazla uzun tutulmamalıdır. 3 yılın uzun olduğunu düşünüyorum. Çocukların BILLSEM'e başladıktan sonra özel yetenekleri kısa sürede belirlenmelidir.

6. olarak \% 43,3 ile "Çerçeve programlar yeniden düzenlenerek etkinlikler zenginleștirilmelidir." gelmektedir. 30 öğretmenden 13 bu öneriyi dile getirmiştir. Katılımcıların açıklamalarından bazıları aşağıda verilmiştir.

Ö3: Etkinliklerin zenginleştirilmesi gerektiğini düşünmekteyim. Birbirini tekrarlayan etkinlikler yerine yeni etkinlikler oluşturulmalıdır. Çerçeve programlar revize edilmeli. Etkinlikler bazı ögrencilere zor bazılarına kolay girebiliyor. Bu nedenle etkinliklerde esneklik sağlanmalı. Öğrenciye, merkezin bulunduğu ile vs. göre ögretmen tarafindan ayarlanmalt.

Ö6: Öğrencilerin ilgisini çekecek maliyeti yüksek olmayan etkinlikler tasarlanmall. Etkinliklerde görsel tamamlayıcıların daha fazla olması gerekmektedir. Sanal gerçeklik çalışmaları bulunmalı. Bunun yanı sıra etkinlikler çeşitlendirilebilir. Video vb. yardımcı materyaller hazırlanabilir.

Ö26: İngilizce Öğretmeni olarak görev yapmaktayım. İngilizce dersi için hazırlanmıs olan çerçeve program ve etkinlikler, çok daha etkili, yenilikçi eğitim yaklaşımlarıyla, oyun temelli ve iletişime dönük hazırlanabilirdi. Bu nedenle programın güncellenmesi gerektiğini düşünüyorum.

Sonra yine \% 43,3 ile "BİLSEM'lere MEB tarafindan daha fazla ödenek ayrılmalıdır." gelmektedir. 30 öğretmenden 13 bu öneriyi dile getirmiştir. Katılımcıların açıklamalarından bazıları aşağıda verilmiştir.

Ö5: Devlet BILSEM'lere ödenek aylrmall. Malzeme odaları olmalı ve etkinlik malzemeleri toplu alınabilmeli. Yeni bilsem binaları hizmete girip prosedüre uygun grup ve sayılarda hizmet vermeli. Normal buna göre ayarlanmalıdir. Aksi halde BILLSEM'de siniflar normal sinif gibi olmakta ve anlamı kalmamaktadir.

Ö9: Kurumumuza verilen bütçe artırllmalıdır. Yaşanan derslik sılkıtısı ve araç gereç sikıntıları için BILSEM'lere yeterli ödenek ayrılmalıdır.

Daha sonra \% 36,6 ile "BİLSEM'e öğrenci seçim süreçleri yeniden düzenlenmelidir." gelmektedir. 30 öğretmenden 11 bu öneriyi dile getirmiştir. Katılımcıların açıklamalarından bazıları aşağıda verilmiştir.

Ö4: Uygulanan zekâ testlerinin güvenirliliğini ve geçerliliğinin tekrar gözden geçirilmesi gerektiğini düşünüyorum. Uygulanan testler revize edilmeli. Bunun yanında Bilsem ögretmenlerine daha fazla yetki verilmeli. Örneğin, öğrencileri seçme sürecinde sıkıntılar olabiliyor. Bilsem ögretmenleri seçme konusunda yetki sahibi olmall.

Ö17: Öğrencilerin küçük yaşta BILLSEM'e gelmesi ve branş derslerine girmesinin uygun olmadı̆̆ını düşünüyorum. Özellikle görsel sanatlarda nitelikli eğitimin olabilmesi için öğrenci yaşlarının gerekli olgunlukta olması gerekir. Bilim Sanat merkezine öğrenciler kas beyin koordinasyonu ve bilinç düzeylerinin yüksek olduğu bir yaşta alınmalıdırlar.

Sonra yine \% 36,6 ile "Kurum içi iletişim güçlendirilmeli." gelmektedir. 30 öğretmenden 11 bu öneriyi dile getirmiştir. Katılımcıların açıklamalarından bazıları aşağıda verilmiştir. 
Ö2: Yönetim-öğretmenler arası iletişimi güçlendirmek için ayda bir sorunların, çözüm önerilerinin konuşulacağı organizasyonlar yapılmalı. İdareciler arası iletişsim kuvvetlendirilmelidir. Kurumun öğretmenler için sosyal aktiviteleri artırılmalıdır. Kurumdaki tüm personele fiziki imkânlar ve materyaller eşit olarak dağıtılmalıdır.

Ö7: Öğretmenler odası daha aktif kullanılmalı. Öğretmenler bir araya geldiğinde genel sohbetlerin dışında konu dönüp dolaşıp öğrenci değerlendirmesi ne gelir öğrencilerimizi sadece kendi branşımız açısından değil çok yönlü tanıma şansı doğar. Bu durum branşlar arası işbirliğini güçlendirir. Hiçbir sanal paylaşım doğal iletişimin yerini tutamaz.

Daha sonra \% 33,3 ile "Öğrencilerin devamsızlık durumu sıkı takip edilmelidir." gelmektedir. 30 öğretmenden 10 bu öneriyi dile getirmiştir. Katılımcıların açıklamalarından bazıları aşağıda verilmiştir.

Ö6: Devamsızlık daha sıkı takip altına alınmalı ve devam etmeyen öğrencilerin merkez ile ilişikleri kesilmelidir. BILLSEM'e hiç gelmeyen ögrenciler var. Bunların bazılarının kaydı siliniyor, bazılarının silinmiyor.

Ö9: Devamlılık konusu daha ciddiye alınmalı. Devamsızlık ve zaman konusu için farklı planlamalar yapılabilir. Devamsızlık problemini çözmeye çalışarak öğrencilerin dersleri kaçırmaması sağlanmalıdır.

Son olarak \% 26,6 ile "Bilsem öğretmenlerinin özlük hakları iyileştirilmeli." gelmektedir. 30 öğretmenden 8 bu öneriyi dile getirmiştir. Katılımcıların açıklamalarından bazıları aşağıda verilmiştir.

Ö16: Bilsem de görev yapan ögretmen ve yöneticilerin özlük hakları iyileştirilmeli. Tayin sılkıntıları çözülmelidir. Il dışı tayin istediğimizde başka bir BILLSEM'i tercih edemiyoruz. Bunun çözülmesi lazım.

Ö29: Bilim sanat merkezinde çalışan öğretmenlerin özlük haklarının artırılması gerekir. Donanıml, bilgili, kendini geliştirmiş ögretmenlerin BILSEM'leri tercih etmesi teşvik edilmelidir. BİLSEM'de çalışan ögretmenler farklı bir statüye kavuşturulmalıdır.

Öğretmenlere göre Bilim ve Sanat Merkezlerinde çalışma saatleri normal okullardaki gibi gündüz olmalıdır. $\mathrm{Bu}$ durum hem öğretmenlerin hem de öğrencilerin motivasyonunu artıracaktır. MEB tarafından verilen ödenekler artırılarak fiziki donanım noktasında BİLSEM'lere destek olunmalıdır. Velilere yönelik seminerler düzenlenerek BILLSEM'deki süreçler hakkında bilgi sahibi olmaları sağlanmalıdır. Öğrencilerin alanlara ayrılması sürecinde velilerle iletişim içinde olunmalıdır. Devamsızlık sorunları takip edilerek gerekli önlemler alınmalıdır. Bilim ve Sanat Merkezlerinde uygulanan programlar güncellenmelidir. Programda üstün yetenekli çocuklara uygun etkinliklere yer verilmelidir. Merkezlerin öğrenci mevcutları ve kapasiteleri dikkate alınarak BİLSEM sınav süreçleri yeniden düzenlenmelidir. BİLSEM'de görev yapan öğretmenlerin özlük haklı iyileştirilmeli, kadro ve atama sıkıntıları çözüme kavuşturulmalıdır.

\section{Sonuç ve Tartıșma}

Araştırmada Bilim ve Sanat Merkezinde çalışan öğretmenlerin kurumlarında yaşadıkları sorunlar ve bu sorunlara yönelik çözüm önerilerine ilişkin görüşleri incelenmiştir.

Araştırma sonucunda öğretmenlerin sorunları kişisel, eğitsel ve yönetsel sorunlar olmak üzere üç boyutta ortaya çıkmıştır. Ayrıca öğretmenler bu sorunların çözümü ile ilgili neler yapılabileceğine dair öneriler sunmuştur.

Öğretmenlerin yaşadıkları kişisel sorunlar yorumlanırsa; öğretmenlerin en çok yaşadıkları kişisel sorun çalışma saatlerinin uygun olmamasıdır. BİLSEM'lerde derslerin hafta içi akşam ve cumartesi günleri olması ögretmenlerin yaşamlarını birçok yönden olumsuz etkilemektedir. 
Araştırmada elde edilen bulgu Çetin ve Doğan'ın (2018) çalışmasının sonuçları ile örtüşmektedir. Araştırmada öğretmenler, akşam ve cumartesi çalışmalarından dolayı sosyalleşme sorunları yaşadıklarını ve cumartesi çalışmalarından dolayı hafta sonunda açılan destekleme ve yetiştirme kurslarında, sınavlarda görev alamamaları nedeniyle özlük haklarında ve maddi durumlarında kayıplar yaşadıklarını ifade etmiştir.

Araştırmanın bir başka sonucu Bilim ve Sanat Merkezlerinde fiziki donanım olarak birçok eksiklik bulunmasıdır. Binaların yetersizliği nedeniyle farklı branştaki öğretmenler aynı sınıfı kullanmak zorunda kalmaktadır. Fiziki donanımın yetersizliği ile ilgili elde edilen bulguları alanyazında yapılan bazı araştırmalar da desteklemektedir (Atlı ve Balay, 2016; Keskin, vd., 2013; Koç, 2016; Kurtdaş, 2012). Son yıllarda özel yetenekli öğrencilerin eğitimi noktasında büyük bir önem kazanan BİLSEM'lerde öğretmenlerin branşına özel donanımlı sınıflarda eğitim verememesi çok çarpıcı bir eksiklik olarak ortaya çıkmaktadır. Kurtdaş (2012) yaptığı çalışmada, üstün yetenekli öğrencilerin eğitimlerini daha etkili sağlayabilmek için her ilde öğrencilerin sayısını karşılayacak nitelikte ve sayıda bina sağlanması gerektiğini vurgulamıştır. Bunun dışında bir diğer soruna bakılırsa öğretmenler derslerine ve yapılan etkinliklere karşı öğrencilerin ilgisiz davrandığı belirtmektedir.

Öğretmenlerin yaşadıkları eğitsel sorunlar yorumladığında; öğretmenlerin tamamına yakınının yapacağı etkinliklerde eğitsel araç-gereç ve materyal eksikliği yaşadığı ortaya çıkmaktadır. Aynı zamanda sınıflarda teknolojik destek ve internet altyapısı da yetersizdir. Sarı ve Ögülmüş'ün (2014) araştırmasına göre Bilim ve Sanat Merkezlerinde kaynak ve materyal yetersizliği sebebiyle etkinliklerin tam olarak gerçekleştirilemediği belirlenmiştir. Öğretmenlerin yoğun olarak ifade ettiği diğer sorun ise Bilim ve Sanat Merkezlerinin çerçeve programlarında yer alan etkinliklerin içerik bakımından sorunlar içermesidir. Bazı etkinlikler öğrencilerin sıkılmasına neden olmaktadır. Çetin ve Doğan (2018) yaptıkları araştırmada çerçeve öğretim programında yer alan etkinliklerin sırasının, süresinin ve seviyesinin uygun olmadığını, bilimsel hata içerdiğini, öğrencilerin ilgisini çekmediğini ve okullarda uygulanan öğretim programı ile uyuşmadığını tespit etmişlerdir. Bu sonuçlar da bu araştırmanın bulguları ile benzerlik göstermektedir.

Üstün yetenekli öğrenciler okuldan çıkıp yorgun bir şeklide BİLSEM'e geldikleri için derslere karşı isteksiz davranmakta ve birtakım davranış sorunları göstermektedirler. Teneffüs süreleri de kısa olduğu için dinlenmeye vakitleri yoktur. Bu yüzden zaman zaman devamsızlık da yapmaktadırlar. Lovecky'e (1995) göre de özel yetenekli öğrencilerde bu problemlerin ortaya çıkması şaşırtıc1 değildir. $\mathrm{Bu}$ araştırmada öğrencilerdeki problemler motivasyon düşüklüğü, devamsızlık, kendini üstün görme, ön plana çıkma isteği ve arkadaşlarına ve öğretmenlerine karş1 uygunsuz davranışlarda bulunmadır. Bu sorunların nedenlerinden biri de velilerin çocuklar üzerinde aşırı beklenti içine girmesidir. Aileler BİLSEM'i kazanan çocuklarının bir an önce projeler yaparak ülke çapında dereceler kazanmasını beklemektedir. Bu beklentiler aynı zamanda velilerin kurumla iletişim içinde olmadıklarını ve BİLSEM işleyişini bilmediklerini göstermektedir.

Öğretmenlerin yönetsel açıdan yaşadıkları sorunlara bakıldığında yöneticilerle iletişim sorunları yaşadıkları ortaya çıkmaktadır. Bu sorunun en önemli nedeni yöneticilerin kurumun başarılı olması için sonuç odaklı düşünmesidir. Yöneticiler öğretmenlerden projeler yapmalarını ve ülke çapında başarılar kazanmalarını beklemektedir. Bunun yanında yöneticiler öğretmenlere sunulan olanaklar noktasında eşit davranmamaktadır. Bazı öğretmenlerin sınıfları 3-4 kişilik olurken bazı öğretmenler 15-20 kişilik sınıflarda ders yapmaktadır. Bu durum öğrenci gruplarını dengesiz bir hale getirmektedir. Kurnaz (2014), yaptığı çalışmada BİLSEM'lerin işlevsel hale gelebilmesi ve gelişmesi için yöneticilerin çok önemli olduğunu belirtmekte; idarecilerin liderlik ve profesyonel özelliklere sahip vizyoner kişiler olmaları gerektiğini dile getirmektedir. Araştırmanın ortaya çıkan sonuçlarına göre bu noktadaki sorunların devam ettiği görülmektedir. Sorunların nedenlerinden biri 
de yöneticilerin kendi aralarındaki iletişimsizliktir. Yöneticiler arasındaki sorunlar öğretmenlere de yansımakta ve kurum içi iletişimi zayıflatmaktadır.

Öğretmenlerin yaşanan sorunlara ilişkin önerileri incelendiğinde, öğretmenler mesai saatleri ile ilgili yaşadıkları probleme Bilim ve Sanat Merkezlerinde çalışma saatlerinin normal okullardaki gibi gündüz olması şeklinde öneri sunmuşlardır. Buna yönelik olarak MEB bir düzenleme yaparak öğrencilerin okullarında bir gününü boşaltıp BİLSEM'e daha rahat gelmelerini sağlayabilir. Bu durum hem öğretmenlerin hem de öğrencilerin motivasyonunu artıracaktır. Öğretmenler yaşanan araç-gereç ve materyal eksikliği sorunlarına çözüm olarak ise MEB'in BİLSEM'lere verilen ödeneklerin artırılması gerektiğini ifade etmişlerdir. Bu sayede fiziki donanım noktasında BİLSEM'lere destek olunabilir.

Öğretmenlere göre velilerle yaşanan iletişim problemleri onlara yönelik seminerler düzenlenerek çözülebilir. BİLSEM'deki eğitim süreçleri hakkında bilgi sahibi olmaları sağlanmalıdır. Öğrencilerin devamsızlık problemleri de hem idare hem aile tarafından sıkı bir şekilde takip edilerek çözüme kavuşturulabilir. Ayrıca öğrencilerin alanlara ayrılması sürecinde de velilerle iletişim içinde olunmalıdır.

Öğretmenler çerçeve programın uygulanması ile ilgili yaşadıkları probleme, programlar yeniden gözden geçirilerek güncellenmelidir önerisini ifade etmişlerdir. Programda üstün yetenekli çocuklara uygun etkinliklere yer verilmelidir. Öğretmenlerin sorunlara yönelik diğer çözüm önerileri; "Merkezlerin öğrenci mevcutları ve kapasiteleri dikkate alınarak BİLSEM sınav süreçleri yeniden düzenlenmelidir." ve "BİLSEM'de görev yapan öğretmenlerin özlük haklı iyileştirilmeli, kadro ve atama sıkıntıları çözüme kavuşturulmalıdır." şeklindedir.

\section{Öneriler}

$\mathrm{Bu}$ bölümde çalışmada elde edilen bulgular ve araştırmanın sonuçlarından yola çıkarak aşağıdaki öneriler getirilmiştir.

1) BİLSEM'lerin işlevlerini yerine getirebilmeleri için fiziki donanımlarının iyileştirilmesi, araç-gereç ve materyal eksikliklerinin giderilmesi ve internet altyapısı sorunlarının çözülmesi gerekmektedir.

2)Özel yetenekli öğrencileri doğru şekilde desteklemek için yönetici, öğretmen ve veliler arasında işbirliği sağlanmalıdır.

3Bilim ve Sanat Merkezlerinin statüsü ile ilgili düzenlemeler yapılarak çalışma saatleri hem öğretmenlere hem de öğrencilere uygun olacak şekilde ayarlanmalıdır.

4) Öğretmenlerin sosyal hakları, özlük hakları ve maddi olanakları iyileştirilmeli; norm kadro ve atama sıkıntıları çözüme kavuşturulmalıdır.

5)BİLSEM'lerde uygulanan etkinlikler bilimsellikleri ve öğrenci seviyesine uygunluğu bakımından incelenmeli, eksik noktalar düzeltilmelidir. Çerçeve programdaki etkinlikler her yıl yenilenmeli, özgün içerikler oluşturulmalıdır.

6) Merkezlerdeki öğretmenlerin daha donanımlı olması için çeşitli hizmet içi eğitim, kongre, sempozyum ve seminerlere katılımları teşvik edilmelidir.

7) Başka ülkelerde Bilim ve Sanat Merkezi denkliğindeki kurumlar incelenmeli, dünyadaki gelişmeler takip edilmeli ve yararlı olabilecek uygulamalar örnek alınarak kullanılmalıdır. 


\section{Kaynakça}

Ataman, A. (2004). Üstün zekâlı ve üstün özel yetenekli çocuklar. Üstün yetenekli çocuklar, 158159.

Atlı, H. ve Balay, R. (2016). Bilim ve sanat merkezindeki üstün yetenekliler eğitiminin sürdürülebilirliğine ilişkin öğrenci düşünceleri [Student perceptions towards sustainability of education of gifted students in science and art center]. Kırşehir Ĕgitim Fakültesi Dergisi (KEFAD, ) 17(2), 191-205.

Batdal Karaduman, G. ve Elgün Ceviz, A . (2018). Bilim ve Sanat Merkezi Öğretmenlerinin Eğitim Sürecinde ve Öğrenci Yönlendirilmesinde Yaşadıkları Sorunlar. Journal of Continuous Vocational Education and Training, 1 (1), 1-17. Retrieved from http://dergipark.org.tr/jcvet/issue/42201/497391

Çetin, A. ve Doğan, A. (2018). Bilim ve sanat merkezlerinde görev yapan matematik öğretmenlerinin karşılaştıkları sorunlar. Ankara Üniversitesi Eğitim Bilimleri Fakültesi Özel Eğitim Dergisi, 19(4), 615-641. doi:10.21565/ozelegitimdergisi.370355

Gross, M. U. (1998). The "me" behind the mask: Intellectually gifted students and the search for identity. Roeper Review, 20(3), 167-174.

Gökdere, M. ve Çepni, S. (2003). “Üstün yetenekli çocuklara verilen değerler eğitiminde öğretmenin rolü”, değerler eğitimi dergisi, ss.93-103.

Karasar, N. (2005). Bilimsel Araştırma Yöntemi (15. baskı). Nobel Yayınları.

Keskin, M. Ö., Samancı N. K. ve Aydın S. (2013). Bilim ve sanat merkezleri: Mevcut durumları, sorunları ve çözüm önerileri [Science and art centers: Current status, problems, and solution proposals]. Üstün Yetenekli Ë̆itimi Araştırmaları Dergisi, 1(2), 78-96.

Koç, İ. (2016). Üstün zekâlı ve üstün yetenekli öğrenci velilerinin bilim ve sanat merkeziyle ilgili görüşleri: Bir BİLSEM örneği [Opinions of parents of gifted and talented students about science and art center: A sample of a Science And Arts Center]. Üstün Zekâlılar Eğitimi ve Yaratıcllı Dergisi, 3(3), 17-24.

Kurtdaş, M. Ç. (2012). Üstün yetenekliler ve üstün yeteneklilerin eğitiminde bilim ve sanat merkezleri (Malatya Bilim ve Sanat Merkezi örneği) [Gifted students and the education of gifted students in science and arts centers (Malatya Science and Arts Centers case)]. Hikmet Yurdu Düşünce-Yorum Sosyal Bilimler Araştırma Dergisi, 5(10), 151-181.

Lovecky, D. V. (1995). Highly gifted children and peer relationships. Counseling and Guidance Newsletter, 5(3), 2-7.

Milli Eğitim Bakanlığı Özel Eğitim Hizmetleri Yönetmeliği, (2018). http://www.resmigazete.gov.tr/eskiler/2018/07/20180707-8.htm (Erişim tarihi: 06.02.2019).

Sarı, H. (2013). "Türkiye'de Üstün Yetenekli Çocukların Eğitim Gördüğ̈̈ Bilim Ve Sanat Merkezleri İçin Öneriler-Editöre Mektup", Journal of Gifted Education Research, 1(2), ss.146-149.

Sarı, H. ve Ögülmüş, K. (2014). Bilim ve sanat merkezlerinde (BİLSEM) karşılaşılan sorunların öğretmen ve öğrenci görüşleri açısından değerlendirilmesi [Evaluation of the problems faced by teachers and students in science and art centers]. Uluslararast Türk Ĕgitim Bilimleri Dergisi, 2(2) 254-265.

Silverman, L. K. (1994). The moral sensitivity of gifted children and the evolution of society. Roeper review, $17(2), 110-116$. 
Yalçın, N. ve Diğerleri (2009). Hacettepe Üniversitesindeki Makalelerin Niteliği: İçerik Analizi. I. Uluslararası Türkiye Eğitim Araştırmaları Kongresi, 1-3 Mayıs Çanakkale .

Yıldırım, A. ve Şimşek, H. (2013). Sosyal Bilimlerde Nitel Araştırma Yöntemleri. Seçkin Yayıncılık. 